\title{
Beyond Pakistani Harem: Women's Spaces, Neo-colonial Patriarchy and Agency in My Feudal Lord by Tehmina Durrani
}

\author{
Inbisat Ali \\ Kinnaird College for Women Lahore \\ Pakistan \\ Taimur Ali \\ Government College Sheikhupura \\ Pakistan
}

\begin{abstract}
This research explores the metaphorical representation of harem, a quintessential signifier for Orientalist women in Durrani'sMy Feudal Lord from the theoretical perspective of Mernissi (1994). The paper addresses the polemical question how Pakistani women in particular and Neo-colonial Muslim women in general, exercise agency when placed in the harem (literal and metaphorical). The analysis of the text brings out that in contrast to the Orientalist representation of harem by the colonizer, Neo-colonial women writers in general and Durrani in particular provide an authentic representation of harem, its purpose and how it is misused and misrepresented. While doing so, Durrani contributes to the project of postcolonial women writers who write back to the empire, rewrite the Orientalized spaces and challenge the essentialist depiction of Muslim women as oppressed, eroticized and exotic.
\end{abstract}

Keywords: Neocolonial Patriarchy, harem, Feudalism, Pakistan, My Feudal Lord

\section{Introduction}

The word harem has originated from the Arabic word harim which refers to the women members of the family. However, the Orientalist discourses have associated harem with Imperial Ottoman harems which mainly consist of concubines, wives and slave girls. Harem's monolithic impression has been reiterated through countless Orientalist paintings like Lewis's In the Bey's Garden (1865) and Delacroix's The Women of the Algiers in Their Apartment. Even after the demise of the Ottoman Empire, such discourses continue to propagate the Muslim women as exotic and subjugated. Contemporary Islamic feminists contest the diminutive representations of Muslim women's identity and sexuality through the signifier of harem. Instead, these writers depict harem authentically, highlight the significance of women's space and how harem, or the women's private space becomes her battleground for political struggle and selfempowerment.

The exposition of the paper brings out some of the authentic representations of harem by Mernissi (1994). In the light of Mernissi's ideas, Durrani's text will be studied to unveil the concept of harem prevalent in neo-colonial patriarchal Pakistan and how the Pakistani Muslim women negate and contest their identities in relation to their spaces. Harem then acquires new meanings in relation to its occupants. The analysis aims at bringing out the strategies of empowerment adopted by Pakistani Muslim women as they re-negotiate their identities and the meaning associated with their space.

My Feudal Lord was written by Durrani in 1994. The text focuses on Durrani's second marriage with the feudal lord and the politician Mustapha Khar. The book unveils the personal life of Durrani as well as political herstoryof Pakistan. While doing so, it explores how women's private space is governed by patriarchal rules, how these rules are inscribed in her mind through cultural norms and make her carry a harem within at all times. The book also provides an insight into the Feudalist culture in Pakistan and how this culture is used as a tool to subjugate women.

Mernissi's Dreams of Tresspass: Tales of Harem Girlhood (1994) is a semi-autobiographical book, which explores how feminine spaces are perceived in Moroccan culture in particular and Arab culture in general. Although both Durrani and Mernissi belong to and write about different cultures, yet they try to find the answer to the same question: how gendered spaces and identities are perceived in ne-colonial patriarchal era, in a pre-dominantly Muslim country, and how women renegotiate their spaces and identities to empower themselves and exercise agency. Mernissi takes off by exploring the meanings associated with harem and recounts her personal experiences along with references to Arab history to prove how harem becomes a site for women's empowerment and struggle against patriarchy. 
Durrani writes about zanana, a metaphorical variant of harem in Urdu, to point out how women's space becomes a locus of political struggle and rise from a victim to victor.

\section{Theoretical Framework}

\section{1-Neo-colonial patriarchy and Neo-colonial harem}

Bacik (2008, p.39) points out that the term "neo-colonial patriarchy" is a result of an encounter between "European modernity and Arab patriarchy." He further calls it, 'marriage between imperialism and patriarchy' which originates from the Salaffiya movement in the Middle East. Salaffiya movement aimed at return to and implementation of Islamic dogmas in response to Western Imperialism. It played an important role in establishing Neo-colonial patriarchy, a set of gendered norms and culture which shape masculinities and femininities. Neo-colonial harem originates as a result which identifies women's space as segregated from the outside world. In the context of Pakistan, Neo-colonial patriarchy flourished after the partition in 1947 to ameliorate the impact of kufr or falsehood resulting from the British Imperialism. It gained momentum in different political eras and established itself as a code of ethics about women's personal and private spaces, their moralities and worldview. The narrative of Islamic Feminist writers in general and Pakistani feminist writers in particular try to uncover the historical meanings associated with harem, and how the contemporary Muslim women make harem a site of national political struggle and struggle against patriarchy.

\section{2-Multi-layered meaning of harem in Mernissi's Tales}

The purpose of harem, according to Mernissi, is to safeguard frontiers. She writes, 'I was born in a harem in 1940 in Fez', 'south of Madrid, one of the dangerous capitals of the Christians'; she further postulates that she 'was born in the midst of chaos, since neither Christians nor women accepted the frontiers' (1994, p.1) or hudud. So harem had been justified as an attempt to keep harmony in the era of confrontation with the other, the Christians, by keeping the women behind frontiers. However, in the very beginning, we find the women struggling against this frontier by fighting with the door keeper of harem and their struggle is paralleled to the arrival of armed forces. Later Mernissi, revisits the topic and explains the meaning of harem in the following words of Chama:

"The word "harem," she said, was a slight variation of the word haram, the forbidden, and the proscribed. It was the opposite of halal, the permissible.... The same thing applied to a harem when it was a house belonging to a man. No other men could enter it without the owner's permission, and when ' they did, they had to obey his rules. A harem was about private space and the rules regulating it. In addition, Yasmina said, it did not need walls. Once you knew what was forbidden, you carried the harem within. You had it in your head, "inscribed under your forehead and under your skin." (Mernissi, 61)

According to Chama, harem is a set of rules inscribed under the skin of people and they have to follow it at all times. Mernissi further identifies that the rules about space and code of conduct are made by men and they are not in the favor of women.

"Maybe the rules are ruthless because they are not made by women," was Yasmina's final comment. "But why aren't they made by women?" I asked. "The moment women get smart and start asking that very question," she replied, "instead of dutifully cooking and washing dishes all the time, they will find a way to change the rules and turn the whole planet upside down." "How long will that take?" I asked, and Yasmina said, "A long time." (p.63)

Besides highlighting the boundaries which limit women, Mernissi observes how women survive and acquire power through the depiction of different characters. She represents the traditional, powerful Arab woman in the depiction of Oum Kelthoum. 'the self-assured woman' representing 'noble things' and aristocratic, Asmahan, who likes to wear 'Western blouses' and wants to 'dress up' and 'dance away' (Mernissi, 1994, pp.104-105). Particularly the depiction of Asmahan living 'life on the run, tasted everything in a rush' emphasizes the desire to escape traditionalism and the boundaries, for early twentieth century Arab women (Mernissi, 1994, p.106).Harem, according to Mernissi becomes a space where women challenge and question the man-made rules, empower themselves by sharing knowledge and share the bond of sisterhood. In this way, harem becomes a site where women express their multiple identities and exercise various strategies for their empowerment and self-expression.

\section{Discussion and Analysis}

\section{1-Zanana and the man-made rules in My Feudal Lord}

My Feudal Lord represent harem as a space where women's bodies are controlled through violence, veiled and hidden from the outside world and eroticized as an object of man's carnal pleasures. Durrani recounts, "There was not a day that Mustafa did not hit me... I just tried my best not to provoke him...” (Durrani. 1995, p. 118) She had to obey Khar at all times. 
When she was pregnant, she had to obey his directions on insignificant matters like eating and drinking, "Mustafa insisted that I started my day by consuming buttered parathas and eggs" (Durrani, 1995, p. 99)By the time I was eight months' pregnant, Mustafa's rich, force-fed diet had caused me to balloon from my normal eight stone to almost eleven stone. I looked and felt like a bloated cow" (Durrani, 1995, p. 109) this physical abuse and violence came to an end when Khar had to leave for England where he was provided residence by Durrani's parents. "This is my father's house and I do not think you should dare to lift a hand on me" (Durrani, 1995, p. 225). This financial support allowed Durrani to stand up against the tyranny and oppression, "The next time you will raise a hand on me, I will pick a-up a knife and kill you" (Durrani, 1995, p. 215).Challenging the monolithic identities for Muslim women, and the rules of zanana, Durrani depicts how she resisted to all forms of violence and became powerful at various instances.

\subsection{1- Private and public spaces: harem as a site of political struggle}

When Durrani married Khar, the Pakistani feudal harem that she started living in, was very much similar to the one represented in the colonizer's discourse. Women were confined in private domains and they were not allowed to take part in public spheres. In the text under discussion, it has been mentioned that women "became part of zanana (women's chambers) where in every sense the male was the king and female slave (Durrani, 1994, pp. 45). Women in zanana were supposed to fear men. "My love for the man had now turned into fear. I knew that anything that I might say or do could make him angry" (Durrani, 1995, p. 106) Durrani posits how she later stood up against oppression and exercised agency by developing her interest in politics. Consequently, harem becomes a place of heated political discussions, struggle and political meetings. Durrani observes, "He discussed politics with me and expected me to take an active interest in his work" (Durrani, 1995, p. 107) Furthermore, she emerged as a strong political leader, more determined and courageous than her husband. She was determined not to leave Pakistan after General Zia took over the country and fight alongside with Bhutto, whereas, Khar sought a safe passage out of the country,"But I lay awake most of the first night, embarrassed that we had run away, leaving Bhutto in what was certainly his death cell I did not know how Mustafa had arranged passage out of the country, but something told me that something had bartered his honour for his life" (Durrani, 1995, p. 121)Even when they moved back to Pakistan from England, she displayed strength and courage. Mustafa was imprisoned and Tehmina actively took part in politics, moving independently from one city to another. Durrani's text echoes Mernissi's tales of harem where women were aware of and interested in the political struggles of the time and they were not hesitant to express their opinion about it. The harem women in Mernissi's text discussed current affairs like the divorce of Egyptian Princess Farida after she fails to produce a male heir. They also express their disgust and hatred for King Farouk by naming their peacock after him. The women depicted in such texts challenge the concept of harem and its activities reduced to domestic affairs. Rather these women can be seen as strong political leaders having their own opinions and sometimes more courageous than their male counterparts.

\subsection{2- Tales of Physical violence and resistance in Pakistani harem}

Physical beating and violence is a common practice in Pakistani harem. Khar had a violent relationship with Tehmina. There are several instances mentioned in the text where he gave her severe physical beating "Mustapha beat me with increased venom, until my screams weakened to tired whimpers and I was nearly unconscious" (Durrani, 1994, pp. 134). However, there came a time when she started retaliating and responded by being equally violent. "I grabbed the pot from the stove and threw it at him. He screamed in pain from the burning brew" (Durrani, 1994, pp.188). This shows the resistance shown by Durrani against the violence and how she becomes powerful by retaliating against it. This also indicates the fluid identities of Muslim women.

\subsubsection{Sexual relationship and passivity}

The other common patriarchal practice mentioned in the text regarding female body was men being dominant in sexual relationships. Women were supposed to play a passive role and were not even allowed to show any signs of pleasure "his class believed that a woman was an instrument of man's carnal pleasure. If the woman ever indicated that she felt pleasure, she was a potential adulteress" (Durrani, 1994, pp. 106). In the text each time Khar asked for a sexual relationship she had to silently present herself. Furthermore she did not have the ownership of her body. She was supposed to eat, drink and look the way her husband wanted her. "Mustafa insisted that I started my day by consuming buttered parathas and eggs," (Durrani, 1995, p. 99) and also drink fresh cow's milk. He believed, "the regimen was nutritious for the unborn child.....By the time I was eight months' pregnant, Mustafa's rich, force-fed diet had caused me to balloon from my normal eight stone to almost eleven stone. I looked and felt like a bloated cow" (Durrani, 1995, p. 109). This submission and passivity ultimately ended and she started claiming the ownership of her body. When a lump was diagnosed in her breast, she went to the best doctor in Karachi, despite the opposition of her husband. She also cut her hair against the wishes of Khar and made her own decision about her identity. The text suggests the powerful status of Pakistani Muslim woman as she exercised a better control over her life. 


\subsubsection{Harem Within; Honor and Shame}

Mernissi postulates that harem aims at preventing fitna meaning disorder or a beautiful woman in Arabic. Fitnacan be prevented not only through physical confinement but also by implementing a man-made code of ethics for women. This code of ethics or set of rules are inscribed in the minds of the women. Muslim feminist writers have challenged this notion and pointed out how the women resisted, showed courage in the face of oppression and asserted their rights by negating the hudood or frontiers. The same concept of psychological harem is reiterated in Durrani's autobiography. According to Durrani, honor and shame are the tools to assert the rules of harem. In the novel under discussion, Durrani mentioned that men did not even allow their wives to go to a male doctor as they considered it an act of shame. They believed that a man's honor will be questioned if he sends the female members of the family to a male doctor for treatment. They preferred women to die instead of taking them to a male doctor. When Tehmina was ill in England and was taken to a male doctor, Khar was furious, "My crime to him was not against my body, but against his honour...D'yourealize that you were examined by male doctors! You have humiliated me" (Durrani, 1994, pp. 138). When they moved to Pakistan and Khar was imprisoned at that time, Tehmina was diagnosed with a lump in her breast which needed biopsy and further treatment if required, Khar again warned her not to go to a male doctor but Durrani showed resistance "I refused point-blank. I'm going to Karachi, I said defiantly. To the best hospital in the country" (Durrani, 1994, pp. 272). Similarly, when Khar's ailing mother was in a serious condition, Mustafa's other younger brothers and men of the family did not allow her to go to a hospital in Multan. It was at that time that Tehmina went to KotAddu and took a decision to take her to hospital in Multan for treatment which shocked the whole family. This shows that the Muslim Pakistani women negate the man-made code of ethics and assert their identity.

\section{2-Family (kinship structures)}

The process of empowerment in harem is largely supported by Durrani's father and brothers. Ironically, her mother does not seem to play a positive role in her empowerment. Durrani's father and brothers have always been supportive and caring towards her. Mohanty quotes in "Under Western Eyes" that the third world women are known as the victims "Arab familial Systems". The familial relations and the kinship structures are not always the source of women subjugation. It varies in different societies and cultures. They provided her with all sorts of financial and moral support at the time of utter distress. When Tehmina came to know about Khar's extra marital relation with Adila, Tehmina's brother Asim and her father bought her a separate apartment in England and bore all expenses of her and children, arranged a recreation trip for her to Spain. Asim fully supported her sister to file a case of divorce against Khar to end the abusive relationship. Such depiction negates the stereotypical representations by white feminists who believed that familial system weakened women, instead her father and brother provided her full support.

\subsection{1-Inside the Walls of Harem: Polygamy and Empowerment}

Harem is associated with polygamy and extra-marital affairs of men in the Orientalized discourses. Such representations position the Muslim women as passive and oppressed and almost never recount the stories of resistance and courage that these women exhibit. In My Feudal Lord it has been mentioned that Durrani was Khar's sixth wife. A detailed account of his previous wives and illicit relationship with other women has been depicted. Durrani challenges the practice of misinterpretation of Koran as a justification for polygamy and highlights the cruelty behind it. Furthermore, she also posits how the women exercise agency when placed in polygamous relationship. Khar'sfirst wife, Wazir was her older cousin, who gave birth to his first born, Abdul Rehman. After the birth of his son, Khar, then a teenager, escaped from his village because he doesn't want to live with her. The elders "dissolved her marriage with Mustafa and gave her to her much younger brother-in-law" (Durrani, 1995, p. 42). In the meantime, "Mustafa befriended a man who had an attractive and somewhat educated sweetheart" (Durrani, 1995, p. 42) when the man knew about her pregnancy, he left her. Khar provided her with a shoulder and married her. She gave birth to a son and within a year gave birth to another son. All these responsibilities were overwhelming and Khar divorced her. His next marriage was with Safia, a PIA airhostess but he banished her to her home village in KotAddu. This is to ensure that the spirit of adventure is completely exorcized from her. By that time, Khar had been an active politician and attended parties "where women were the part of the menu" (Durrani, 1995, p. 49) at one such party, he fell in love with Naubhar, a prostitute. He first took her as a mistress and later married her. He further asked her to keep their marriage a secret. At this point, the political scenario in Pakistan changed and Bhutto took over as a new Prime Minister of the country. He appointed Khar as the Governor of Punjab but by that time, the news of his marriage with Naubhar was out. Bhutto warned Khar that an ordinary prostitute can't be the wife of the Governor of Punjab and he asked her to mend the situation. Khar divorced Naubhar and installed Safia as a respectable wife in Governor House. But at this point, his brothers broke out the news, "your wife has had an illicit relationship with your younger brother, Ghulam Murtaza. We cannot hide this fact from you any longer" (Durrani, 1995, p. 51) Khar divorced her and chose Shahrazad, the beautiful niece of the Education Minister as his fifth wife. 
Bhutto was against this marriage because they both belonged to different social backgrounds but Khar did not pay any attention to Bhutto's concerns. After his wedding, he met Durrani and started a relationship with her, which resulted in his sixth marriage. Even after his wedding with Durrani, he continued to have relationship with other women. Instead of being passive and oppressed, Durrani shows how these women were powerful and stood up against the misogynist feudal culture of Pakistan. She shows her own strategy of resistance which included retaliation against the physical violence through force, "I scratched and shoved him as hard as I could. I clawed at his face and pulled his hair" (Durrani, 1994, pp. 190) Furthermore, she moved to a separate residence when she came to know about Khar's relationship with her younger sister Adila. She even sought legal help in England and got Khar behind the bars when he kidnapped their kids and transported them to Pakistan. This resistance and retaliation ultimately made Khar realize that Durrani was his equal. It was visible when he asked Durrani to sit next to him in his car on their way to attend a political meeting, "He told his brother Ghazi to sit in the back and asked me to sit in the front. It was a progressive gesture, a break from tradition, a signal to others that now I was his equal" (Durrani, 1994, pp. 270) Furthermore, she also sought divorce from him when he continued to have adulterous relationship with Durrani's sister. Durrani's account depicts the brutality behind the polygamy in Pakistani feudal culture. She also highlights how Pakistani Muslim women exercise agency when caught in the polygamous relationship.

\section{3-Neo-colonial harem and state ideologies in Pakistan}

The novel posits how State law and ideology supports neo-colonial harem and the oppression associated with it. Durrani highlights how different political eras impact the State laws towards gender empowerment and disempowerment. The politics inside harem reflect the Pakistani political scenario outside. Durrani's account reflects how the political herstory of Pakistan constantly coincides with her own her story. When Durrani and Khar were in exile after the martial law was declared, Durrani has titled this time period as the "Law of the Jungle" in her book. Jungle's law prevailed in her own life as well. Khar had an extra marital affair with Adila without respecting the sacred bond of marriage. She resisted against it and decided to have a separation. He also kidnapped and transported their children to Pakistan. Durrani sought legal help and put him behind the bars, "He faced a jail sentence in England for kidnapping wards of court [...]Mustafa the hunter became Mustafa the hunted" (Durrani, 1994, pp. 241) This reflects how State ideologies can become instrumental in shaping the power struggle in marital relationship. After Zia's Plane crash incident, it was the time when the couple returned to Pakistan after 9 years of exile. There was some flexibility in the strict notion which was prevalent during Zia's time about "Chadar and Chaardewaari" which confined women to private spaces. Tehmina actively took part in political campaigns. There is an instance mentioned in the text where Tehmina attended a political meeting in Gujrat without covering her head which was a break from a very strict law showing a powerful and independent woman taking part in politics "I was wearing a black and white shirt with red collar and cuffs, my hair freely cascading down my back" (Durrani, 1994, pp. 300). Another instance of the liberty and empowerment granted to her in that political era is when shewent to Muzaffargarh, a conservative town governed by feudal laws, where women were not allowed to come in public or speak with men. Tehmina publically addressed a crowd with confidence. "In Muzaffargarh I faced the task of speaking to a confused crowd of people. Mustafa had sent a woman to speak for him" (Durrani, 1994, pp. 318). This shows that State laws and ideologies have a very important role in shaping gendered identities and political struggle inside harem.

\section{4-Agency}

Durrani becomes powerful and she exercises agency as well by using writing as a tool and by speaking up against all the violence committed.

\subsection{1-Writing as a tool}

Writing becomes a powerful tool for women, as women write with white ink against the phallocentric tradition, "I decided to cast a stone at hypocrisy. I decided to write this book and break the traditional silence" (Durrani, 1994, pp. 375) she further clarifies her point in the following words, "I am a woman, so I naturally write from a feminine perspective. My works are about breaking a silence for a part of society which cannot speak out...I am called bold because these are issues one does not talk about. My passion for reform was overwhelming. And I think, when anything overwhelms you, you have a natural boldness because you step out of realm of fear (p. 29).

Durrani again reflects the ideas of Mernissi who sees writing as a tool of struggle against oppression. Mernissi retells the story of Scheherzad who develops the skill of story-telling and uses it to as a strategy for her survival for 'three years, until the King was unable to imagine living without her' and 'renounced his terrible habit' of beheading women (Mernissi, 1994, pp.15-16) For Durrani, Writing becomes a medium through which she brought her own issues and the issues of other women from periphery to the Centre. 


\subsection{2-Silencing and speaking}

The other way of exercising agency, mentioned by Durrani was speaking out and not remaining silent "I announced 'Jehad'-a movement to represent the silent majority to raise controversial issues that most people feel afraid to speak about" (Durrani, 1994, pp. 381). Instead of being a sexed subaltern, she speaks about the brutality the women face in Pakistani harem and polygamous marriages. She also points out the strategies of empowerment these women exercise and how they stand up against the tyranny and hypocrisy of the feudal culture in Pakistan.

\section{4-Conclusion}

Durrani challenges the absolutist, patriarchal representations of Pakistani women in particular and Muslim women in general by re-inventing women's private and public spaces. Using the signifier of zanana, the closest synonym of harem in Urdu, Durrani depicts how women's space becomes a locus of political struggle, resistance against patriarchy and sisterhood. By doing so, Durrani becomes a part of the project of Islamic feminists who reinvent the Orient by "writing back," to the state's patriarchy and Occidental orthodoxy.

\section{Glossary}

Harem: The term "harem" used by Fatima Mernissi in Dream of Trespass has been derived from the Arabic harem referring to the female members of the family segregated from their male counterparts in the households.

Zanana: It is the part of the house usually in the Indian subcontinent which is reserved for the female members of the family where no male members are allowed.

Kufr: This term is used for the "infidels" or the "non-believers" who reject and disbelieve in Allah and the doctrine of Islam.

Hudud: The hudud represents a traditional concept related to Harem according to which there should be well distinguished borders, boundaries and limits for women in order to prevent moral degradation in the society.

Haram: Haram is an Arabic term used for the acts which are forbidden by Allah

Fitna: Fitna is an Arabic term used for the chaos, trial, affliction and disorder in the society caused by various factors

Chadar and Chaardewari: This was a concept which gained momentum in Pakistan in 1980s during Zia's time according to which the women should be veiled and should remain within the four walls of the house.

Jehad: The struggle or fight against the enemies of Islam is known as Jehad. It is also the spiritual struggle within one self against the sin.

\section{References}

Bacik, G. (2008). Hybrid Sovereignty in the Arab Middle East: The Cases of Kuwait, Jordan, and Iraq. 1st ed. New York; Hampshire: Palgrave Macmillan.

Bourget, Carine. (2013) Complicity with Orientalism in Third World Women's writing: Fatima Mernissi's fictive Memoirs. Research in African Literatures, 44(3), pp 30-49.

Cixous, Helene. (1976). The Laugh of the Medusa.Signs, 1(4),875-893.

Durrani, Tehmina. (1994) My Feudal Lord.London, Corgi Books.

Jones, Rachel Bailey. (2011).Post-Colonial Representations of Women: Critical Issues for Education. NewYork, Springer, DOI. 10.1007/978-94-007-1551-6.

Mernissi, F. (1994) Dreams of Trespass. New York, Perseus Books.

Mohanty, Chandra Talpade. (1984).Under Western Eyes: Feminist Scholarship and Colonial Discourses.Boundary, 12(3), pp 333-358.

Si, Anetha. (2018).Harems, Neo colonial Patriarchies and Understanding Modernity for Postcolonial Maghrebian women in Morocco and Algeria, with reference to the works of AssiaDjebar, Fatima Mernissi (Dissertation). Brunel University, London, England.

Tuglu, Begum. (2016) .Bodies (Re) Gained: Gender and Identity in ElifShafak's Pinhan and Woolf's Orlando. International Journal of Languages, Literature and Linguistics, 2(3), pp. 90-95.

DOI: 10.18178/ijll1.2016.2.3.73. 